Open Access

\title{
Comparing the effectiveness of input-based and output-based activities on productive knowledge of vocabulary among pre- intermediate EFL learners
}

\author{
Ehsan Namaziandost ${ }^{1 *}$, Elham Saberi Dehkordi ${ }^{2}$ and Sajad Shafiee ${ }^{1}$
}

\footnotetext{
* Correspondence:

e.namazi75@yahoo.com

'Department of English, Faculty of Humanities, Shahrekord Branch, Islamic Azad University, Shahrekord, Iran

Full list of author information is available at the end of the article
}

\begin{abstract}
The present study aimed to investigate the comparative impacts of input-based and output-based activities on vocabulary knowledge of Iranian EFL learners. To fulfil this objective, 54 intermediate EFL students out of 70 from a private language institute were chosen through administering the Oxford Quick Placement Test (OQPT). The selected participants were divided into one control group $(n=18)$ and two experimental groups including the input-based group $(n=18)$ and the output-based group $(n=18)$. Afterwards, all three groups took a productive vocabulary test as pre-test. Then, the experimental groups received the treatment. The experimental group 1 (input-based group) received the instruction through input-based activities and the experimental group 2 (output-based group) received the instruction through output-based activities. The whole treatment lasted for 9 sessions of $50 \mathrm{~min}$. After the treatment, the post-test of productive vocabulary test was administered to the all groups. Also, after two weeks, a delayed post-test was administered to the learners to examine the effect of different input and output-based activities on EFL learners' vocabulary retention. The results of, one-way ANOVA, and Scheffe post hoc tests revealed that both input-based and output-based groups outperformed the control group on the post-test and delayed post-tests. However, there was not a significant difference between the performances of the experimental groups on the post-test and delayed post-tests. The findings provide further evidence that both inputbased and output-based activities lead to both productive vocabulary knowledge. In general, the results show similar levels of effects for input-based and output-based activities on vocabulary acquisition. The implications and suggestions for future research are also presented.
\end{abstract}

Keywords: Input-based activities, Output-based activities, Productive knowledge, Vocabulary, EFL learners

\section{Introduction}

No one abnegates the pivotal role that input plays in L2 acquisition. In the meantime, it is generally recognized that exposure to input lonely, however important, may not be sufficient for students to achieve propelled levels of L2 improvement. Notwithstanding the role of input, output has likewise been perceived to assume an urgent role during the time spent for L2 acquisition. There are challenging perspectives with respect

(c) The Author(s). 2019 Open Access This article is distributed under the terms of the Creative Commons Attribution 4.0 International License (http://creativecommons.org/licenses/by/4.0/), which permits unrestricted use, distribution, and reproduction in any medium, provided you give appropriate credit to the original author(s) and the source, provide a link to the Creative Commons license, and indicate if changes were made. 
to the importance supremacy of input or output for L2 acquisition. More particularly, there are studies that propose that the role of output is secondary to the role of input and output solely simplifies access to an already created L2 framework (e.g., Benati, 2005; VanPatten \& Cadierno, 1993; VanPatten \& Wong, 2004). These examinations gave proof that students who received instruction which prohibits any sort of output practice executed also on comprehension and even production assignments as the individuals who had output-based instruction. One type of output-based training is the one rehearsed in customary audiolingual classrooms in which target structures were practiced without any communicative context through various kinds of mechanical drills. VanPatten (1993) reprimanded such customary practice-situated directions not just as a result of the utilization of mechanical drills, yet additionally on the ground that they put "the cart before the horse" by asking students "to create when the creating framework has not yet had the relevant intake data" (p. 436). The discussion over the essential role of input and output in L2 improvement drove researchers to think about the impacts of various kinds of input-based and output-based activities with respect to L2 advancement.

Regardless of the long-running discussion over the roles of input and output in second language acquisition and the various investigations that have analyzed the impacts of the two instructional choices on the acquisition of grammatical highlights, little research has managed vocabulary acquisition. This is reflected in the greater part of rudimentary EFL course books that have regularly utilized production-based instruction (i.e. engaging the students in speaking or writing). However, input-based instruction (i.e. center around students' appreciation of input to request to accomplish the result) may be reasonable for youthful students if we accept that the known attributes of first language (L1) vocabulary acquisition -, for example, quick mapping or broad understanding information preceding production information - are relevant to the second language (L2) acquisition of youthful students. The examination detailed in this article endeavored to research the comparative impacts of input-based and production-based instruction on vocabulary acquisition by youthful EFL students. Literature significant to the two choices for training vocabulary is first checked on before the subtle elements of the study itself are displayed.

\section{Literature review}

Input-based instruction

Ellis (2012) characterizes input-based instruction as a guidance that "includes the control of the input that students are presented to or are required to process" (p. 285). There are diverse types of input-based instruction. One type of input-based instruction appears as VanPatten's model of information preparing and its educational spinoff Processing Instruction (PI) (e.g., Lee \& VanPatten, 2003; VanPatten, 1993, 1996, 2002). In this sort of guidance students are pushed to process input by being requested to demonstrate that they have comprehended the significance of a target element in input by giving a non-verbal or insignificantly verbal reaction, for example, picking between two pictures while listening to a sentence that portrays one of the photos (Ellis, 2012). PI is made out of two primary stages: 1 . Explicit information stage giving a clarification with respect to target structure 2. Structured input activities went for pushing students from 
wasteful and erroneous preparing methodologies (VanPatten, 1996, 2004. For a definite depiction of PI see Wong, 2004a, 2004b.)

Another approach to actualize input-based instruction more appropriate to the investigation is to control the input to some path so as to make some objective highlights more observable to students. This sort of input-based instruction for the most part appears as literary upgrade or input enhancement, likewise addressed in this examination. The two systems can be considered as spotlight on form instruction since they go for attracting students' regard for etymological targets while they are fundamentally occupied with meaning comprehension. Long (1991) conceptualized focus on form as a sort of guidance that "obviously attracts students' attention regarding etymological components as they emerge by chance in exercises whose superseding center is around meaning or communication" (pp. 4-5). The enthusiasm for spotlight on form instruction (also called form-focused instruction) was brought up in 1990s because of research discoveries that recommended that exposure to input alone however important is not sufficient and some sort of formal mediation is required for students to achieve propelled levels of target like ability.

\section{Output-based instruction and L2 development}

As opposed to input-oriented ways to deal with L2 acquisition, there are a few researchers who dispense more positive and causal role to output in improving L2 framework. These researchers do not abnegate the fundamental role of input in L2 acquisition. They do, however, dismiss the view that input alone is adequate for language acquisition and offers ascend to the advancement of linguistic framework (e.g., Izumi, 2002; Krashen, 1985; Swain, 1995; Swain \& Lapkin, 1995; Toth, 2006). Swain (1985, 1995, 2000, 2005), laying out her output hypothesis, expresses that output is as fundamental as input to progressing L2 learning to large amounts of target-like accuracy. Swain (1985) claims that output "pushed" students from the "semantic preparing" required for grasping input to the "syntactic handling" required for encoding meaning (p. 249). Besides, Swain (1985) contends that producing the target language may fill in as "the trigger that powers the student to focus on the methods for articulation required in order to effectively pass on his or her own expected signifying" (p. 249). One essential capacity of output, among others, as indicated by Swain $(1995,2005)$ is helping students see the gap between their linguistic resources and the target language system.

\section{Input-based vs. production-based instruction}

Krashen's input hypothesis (Krashen, 1982, Krashen, 1985, Krashen, 1998) asserted that production serves just to produce understandable input from the interlocutor, and that output does not make a genuine commitment to acquisition. He constructed this case in light of the way that: 1 . output, particularly conceivable output, is too rare; 2 . it is conceivable to achieve large amounts of linguistic competence without output; and 3. there is no immediate proof that output prompts language acquisition (Krashen, 1998).

Swain (1985), and Swain and Lapkin (1995), then again, contended firmly that 'pushed output' drives the student to see L2 components and alter their output, both of which contribute to acquisition. DeKeyser and Sokalski (1996, DeKeyser and Sokalski, 
2001) differentiated production vs. comprehension practice in view of Anderson's (1993) ability procurement hypothesis, guaranteeing that comprehension and production aptitudes in a L2 can create because of training in the respective aptitudes.

\section{Empirical studies on input-based and out-put based instruction}

A number of empirical studies have been done that contrasted the impacts of input practice with output-based instruction with the expect to require students to absolute comprehensible output. Nonetheless, the results of these examinations are opposite. A significant number of these studies uncovered that input-based and output-based are both viable in L2 improvement. A few different studies demonstrated that input-based and output-based instructions are efficacious in expanding SLA to the same extent or degree (Erlam, Loewen, \& Philp, 2009, Farley, 2001b). Some others provided evidence showing that the input-based instruction was more beneficial than the output one. (e.g., Benati, 2005; Farley, 2001a; Lee and Benati, 2009). The outcomes of numerous studies indicated that output-based instruction was premier comparing to input-based one (Allen, 2000; Morgan-Short \& Bowden, 2006; Toth, 2006).

Rassaei (2012) investigated the effects of input and output on the development of L2 knowledge. Participants included 129 third-semester Persian learners of English enrolled in 5 intact EFL classrooms functioning as four experimental groups and one control group. Two experimental groups received two types of input-based instruction, which differed from each other in terms of the saliency and the number of tokens of target structures in the input. Participants in another experimental group received instruction that required them to produce meaningful output that contained target structures. The last experimental group that only received explicit instruction about target structures was included in the study to specify the moderator role of explicit instruction, which was also included in the input-based and output-based instruction. The results of grammaticality judgment, multiple choice grammar, and written production tests administered as pre-test, immediate and delayed post-tests suggested that both input-based and output-based instruction can lead to the development of L2 knowledge. Our findings also support the claim that more obtrusive input in which target structures are more salient to learners has more positive effects on L2 development than just exposing learners to more tokens of target structure.

Asaei and Rezvani (2015) tried to measure up the effects of two methods of teaching collocations (i.e., explicit and implicit) on Iranian EFL learners' use of collocations in writing. The participants in this study were selected from three intact classes consisting of forty-five adult Iranian advanced EFL learners. Two intact classes were selected as the experimental groups (EG/IG) and one other class as the control group (CG). A pretest was administered to determine learners' use of collocations in writing. It consisted of 20 selected words from "Anecdotes in American English" (Hill, 1980). At the end of the study the participants were given 20 selected words to make a complete sentence. The groups were found to perform with considerable differences on the posttest. The results revealed that the group receiving explicit method of teaching collocations outperformed the other two groups in using collocations in sentence writing.

Salimi and Shams (2016) investigated the comparative effects of input-based and output-based task induced activities on EFL learners' autonomy in writing. 35 learners 
were homogenized out of 70 Pre-intermediate EFL learners. The methodology was that at first session, a task of writing - similar to the writing tasks in their book- was given to all the participants in both experimental groups of input-based and output-based. During six treatment sessions some vocabularies related to the writing task is taught to the students. In input-based group the words are just taught and given to learners without asking them to use these words during the process of learning the lessons, but in the output-based group the teacher asks the students to produce the meaning of the words or try to use these vocabularies. At the seventh session, the same task is given to both groups as the post-test to see whether input and output-based instruction has positive effect on the results of their writing production. The writings are assessed in terms of measurements, fluency, accuracy and complexity. The data are analyzed using paired T-test. The paper concludes that output-based task-induced activities were more effective in improving learners' autonomy in Writing.

Malekshahi and Amini Harsini (2017) investigated the effect of form-focused (FoF) tasks on enhancement of Iranian EFL learners' coherent writing. In this regard, the researchers compared the effectiveness of dictogloss (DIG) task as an output-based task and consciousness raising (CR) task as an input-based task on teaching writing coherent text. Prior to the experiment, the researchers divided 60 Iranian Intermediate EFL learners based on their scores on the Preliminary English Test (PET) into two groups. Throughout the research a pre-test and a post-test which had the same format but different topics were run. The instructional treatment continued for 10 sessions which each session lasted $15 \mathrm{~min}$. The required texts which consisted of some cohesive devices were taken from "Elementary Steps to Understanding" book, while the method of teaching, as the name of each group is revealed, was different. After analyzing the gathered data via independent sample t-test, findings revealed that significant, though, the treatment of each group on writing was, there were no significant different between the post-test of these two groups. So, there were not any significant difference between the performance of CR group and DIG group on producing cohesive devices in a text.

Ellis (2012) showed that the results of already done examinations looking at the impacts of input-based and output-based instruction are conflicting and blended. As indicated by VanPatten's processing instruction model, one of the previous investigations' requirements is that they centered for the most part around input-based instruction and did not assess different sorts of input-based instructions, for example, literary improvement or input upgrade. A portion of the investigations gave proof that output has a more effectual role in second language improvement than it has been considered previously, and they utilized output in a more informative setting (e.g., Erlam et al., 2009; Toth, 2006). As Ellis (2012) states, the advantages of input-based and production-based instructions depend on the negotiations that develop while giving the instruction. To this end, we explore the impacts of input-based and output-based activities to 12 vocabulary improvement in an Iranian EFL setting.

\section{Research questions}

RQ1

Do input-based activities have any significant effect on Iranian pre-intermediate EFL learners' productive knowledge of vocabulary? 
RQ2

Do output-based activities have any significant effect on Iranian pre-intermediate EFL learners' productive knowledge of vocabulary?

RQ3

Which instructional approach (input-based activities vs. output-based activities) is more effective in productive knowledge of vocabulary?

\section{Method}

\section{Design of the Study}

The present study had a quasi-experimental pre-test-treatment-post-test design. The three groups received three different types of treatment:

1. Experimental Group 1 (input-based (IB) group): received input-based activities;

2. Experimental Group 2 (output-based (OB) group): received output-based activities; and

3. Control Group: received traditional instruction and taught activities such as (without being exposed to any activity).

The independent variable of this study was two types of instruction, i.e., input-based and output-based activities. The dependent variable was students' vocabulary learning. The participants were at the pre-intermediate level.

\section{Participants}

Fifty-four pre-intermediate EFL students out of 70 from a private language institute were chosen through administering the Oxford Quick Placement Test (OQPT). Their age range was between 14 to 19 . The selected participants were divided into one control group $(n=18)$ and two experimental groups including the input-based group $(n=18)$ and the output-based group $(n=18)$. Each group contained 18 participants. All the participants were male and native speakers of Persian.

\section{Instruments}

\section{Oxford quick placement test (OQPT)}

The first instrument which was utilized in the present study to homogenize the participants was the OQPT. It could help the researcher to have a greater understanding of what level (i.e., elementary, pre-intermediate, intermediate) her participants were at. This test has 60 multiple-choice items and based on it the learners whose scores were 0 to 10 were beginners; the leaners whose scores were 11 to 17 were considered as breakthrough; the learners whose scores were 18 to 29 were elementary; those learners whose scores were 30 to 39 were pre-intermediate; the students whose scores were 40 to 47 were intermediate; the learners whose scores were 48 to 54 were considered as the advanced learners, and those whose scores were 55 to 60 were very advanced learners. Based on the results of this test, 54 pre-intermediate students were regarded as the target participants of the current research. 


\section{Target items}

Fifty-one nouns were first selected from English Vocabulary in Use (Redman, 1997) as target items, as nouns are considered easier for young learners to learn, being more likely to evoke images and are thus more meaningful than verbs or adjectives (Ellis \& Beaton, 1993; Ellis, 1994). In order to select the target nouns, three familiar categories for Iranian students were chosen: animals, jobs, and fruit and vegetables. The main criteria for selecting the items was that Iranian learners had generally seen the real objects or pictures of the items; therefore, the participants were assumed to be familiar with them. Seventeen items were selected for each category. Then, a pilot study was administered on 30 pre-intermediate students to make sure that vocabularies was unknown to the participants. It was revealed the students in the pilot study did not know the meaning of 40 vocabulary. These vocabularies were selected as the target vocabularies. Afterwards, the vocabularies were presented to the participants in four sessions.

\section{Productive vocabulary pre-test}

The second instrument for gathering the needed data to answer the research questions of the study was a productive vocabulary pre-test. The format of the test was adapted from Laufer and Nation (1999). The test was the same for all groups (i.e., input, output, and control) in pre-test, immediate post-test, and delayed post-test. This test was given to determine the students' vocabulary knowledge before receiving the treatment. It consisted of 40 multiple choice items. Each correct answer received 0.5 point, and the incorrect ones received no point. Therefore, the maximum score was 20 . Internal validity of the questions in the test was confirmed by 8 Ph.D. professors who taught English for more than 10 years. The reliability of the test was computed through using KR-21 formula $(r=0.898)$. Before giving the pre-test to the target group, it was piloted on 13 pre-intermediate students to check its feasibility for the target sample.

\section{Productive vocabulary post-test}

The third instrument which was utilized in this study to ascertain the effects of the treatment on the participants' vocabulary learning was productive vocabulary post-test. The post-test was the modified form of the pre-test; indeed, the pre-test was used both as the pre-test and post-test of the study but in the post-test, the order of options and questions was changed to prevent the probable recall of pre-test answers. The post-test was regarded valid and reliable since itwas the modified version of the pre-test.

\section{Productive vocabulary delayed post-test}

The last instrument which was used in this study was a productive vocabulary delayed post-test. Ten days after conducting the post-test, a delayed post-test (a modified version of post-test) was administered to examine the effect of input and output-based activities on EFL learners' vocabulary learning focusing on time interval. The reliability of the test was calculated through using KR-21 formula $(r=0.812)$.

\section{Data collection procedure}

After making the participants homogenous, their proficiency level of English vocabulary knowledge was measured by a productive vocabulary pre-test. Afterwards, the students 
Table 1 One-Sample Kolmogorov-Smirnov Test (Groups' Pre-test, Post-test, and Delayed post-tests)

\begin{tabular}{|c|c|c|c|c|c|c|c|c|c|c|}
\hline & & IB. Pre & IB. Post & IB. Del. & OB. Pre & $\begin{array}{l}\text { OB. } \\
\text { Post }\end{array}$ & $\begin{array}{l}\text { OB. } \\
\text { Del. }\end{array}$ & $\begin{array}{l}\text { Cont. } \\
\text { Pre }\end{array}$ & $\begin{array}{l}\text { Cont. } \\
\text { Post }\end{array}$ & $\begin{array}{l}\text { Cont. } \\
\text { Del. }\end{array}$ \\
\hline N & & 18 & 18 & 18 & 18 & 18 & 18 & 18 & 18 & 18 \\
\hline \multirow{2}{*}{$\begin{array}{l}\text { Normal } \\
\text { Parameters }\end{array}$} & Mean & 8.7222 & 16.6111 & 16.6389 & 8.9444 & 16.7500 & 16.6111 & 9.0278 & 9.3611 & 9.6111 \\
\hline & $\begin{array}{l}\text { Std. } \\
\text { Deviation }\end{array}$ & 2.13667 & 1.25506 & .72367 & 1.84621 & 1.48769 & 1.00814 & 1.73606 & 1.65214 & 1.40958 \\
\hline \multirow{3}{*}{$\begin{array}{l}\text { Most Extreme } \\
\text { Differences }\end{array}$} & Absolute & .163 & .146 & .187 & .189 & .178 & .266 & .163 & .136 & .331 \\
\hline & Positive & .129 & .146 & .187 & .140 & .178 & .266 & .115 & .092 & .162 \\
\hline & Negative & -.163 & -.100 & -.133 & -.189 & -.158 & -.178 & -.163 & -.136 & -.331 \\
\hline \multicolumn{2}{|l|}{ Test Statistic } & .163 & .146 & .187 & .189 & .178 & .266 & .163 & .136 & .331 \\
\hline \multicolumn{2}{|c|}{ Asymp. Sig. (2-tailed) } & $.200^{c, d}$ & $.200^{c, d}$ & $.095^{\mathrm{c}}$ & $.088^{c}$ & $.137^{c}$ & $.092^{c}$ & $.200^{c, d}$ & $200^{c, d}$ & $.089^{c}$ \\
\hline
\end{tabular}

a. Test distribution is Normal

b. Calculated from data

IB Input-Based group, $O B$ Output-Based group, Cont Control group, Pre Pre-test, Post Post-test, Del Delayed post-test

in the experimental groups received the treatment in different ways. The new words were taught to the experimental groups 1 (IB group) and 2 (OB group) through input-based and output-based activities respectively. Each group received 10 lessons (two lessons a week) during the study. The lesson time for each group was set at approximately $50 \mathrm{~min}$. All the lessons for the three groups were taught by the researchers. After the treatment, a post-test was given to the participants to measure the effects of the treatment on the students' vocabulary learning. After two weeks, the delayed post-test was administered to the learners to examine the effect of different input and output-based activities on EFL learners' vocabulary retention.

\section{Data analysis}

In order to analyze the data, Statistical Package for Social Science (SPSS) software version 25 was used. Firstly, Kolmogorov-Smirnov (K-S) test was used in order to check the normality of the data. Secondly, descriptive statistics including means and standard deviation were calculated. Finally, to examine the impacts of the treatment on Iranian EFL learners' vocabulary knowledge, one-way ANOVA, was utilized.

\section{Results}

\section{Normality test}

Before embarking on choosing appropriate statistical test, it deemed necessary to test the normality of the data which was estimated through employing Kolmogorov-Smirnov (K-S) test of normality (Table 1 ).

Table 2 Descriptive Statistics (Pre-tests)

\begin{tabular}{|c|c|c|c|c|c|c|c|c|}
\hline & \multirow[t]{2}{*}{ N } & \multirow[t]{2}{*}{ Mean } & \multirow{2}{*}{$\begin{array}{l}\text { Std. } \\
\text { Deviation }\end{array}$} & \multirow{2}{*}{$\begin{array}{l}\text { Std. } \\
\text { Error }\end{array}$} & \multicolumn{2}{|c|}{$\underline{95 \% \text { Confidence Interval for Mean }}$} & \multirow[t]{2}{*}{ Minimum } & \multirow[t]{2}{*}{ Maximum } \\
\hline & & & & & Lower Bound & Upper Bound & & \\
\hline IB Group & 18 & 8.7222 & 2.13667 & .50362 & 7.6597 & 9.7848 & 5.00 & 12.00 \\
\hline OB Group & 18 & 8.9444 & 1.84621 & .43516 & 8.0263 & 9.8625 & 5.50 & 12.00 \\
\hline Control Group & 18 & 9.0278 & 1.73606 & .40919 & 8.1645 & 9.8911 & 6.00 & 11.50 \\
\hline Total & 54 & 8.8981 & 1.88184 & .25609 & 8.3845 & 9.4118 & 5.00 & 12.00 \\
\hline
\end{tabular}


Table 3 One-Way ANOVA (Pre-test)

\begin{tabular}{llllll}
\hline & Sum of Squares & df & Mean Square & F & Sig. \\
\hline Between Groups & .898 & 2 & .449 & .123 & .885 \\
Within Groups & 186.792 & 51 & 3.663 & & \\
Total & 187.690 & 53 & & & \\
\hline
\end{tabular}

As seen in Table 1, all significant values in Kolmogorov-Smirnov (K-S) tests were higher than confidence level of 0.05 . This indicates that data were normally distributed. In this case, the parametric statistics like one-way ANOVA can be used to get the final results (Table 2).

\section{One-way ANOVA for pre-tests}

Table 2 depicts the descriptive statistics of all three groups on the pre-tests. Based on the above table, the mean of Input-Based group on the pre-test is 8.7222; the mean of Output-Based group on the pre-test is 8.9444, and the mean of Control group is 9.0278. As it is shown in the table, all the three groups had almost equal performance on the pre-tests. Their mean scores are a testimony for our claim (Table 3).

A one-way between groups ANOVA was conducted to vocabulary production through vocabulary instruction modes (i.e., input-based activities, output-based activities, and traditional instruction). Subjects were divided into three groups. Since the Sig $(.885)$ is greater than 0.05 , the difference between the groups is not significant at $(p<$ $0.05)$. In effect, all the three groups performed the same on the pre-test.

\section{One-way ANOVA for post-tests}

Table 4 shows the descriptive statistics of the post-test of the three groups. The mean score of the participants in the Input-Based group was (16.6221). The mean score of the participants in the Output-Based group was (16.7500) and the mean score of the participants in the Control group was (9.3611). In terms of mean scores among the three groups, significant differences were observed between groups 1 and 2 with group 3 (Table 5).

The above table indicates the analysis of post-test scores of all three groups. Since the Sig. (.000) is less than 0.05 , the difference between the groups is significant at $(\mathrm{p}<$ 0.05 ). It can be claimed that the treatment affected the performance of the groups in the post-test. However, the Post-hoc Scheffe Test can show the exact difference between the groups. The results are presented in Table 6.

Table 4 Descriptive Statistics (Post-Tests)

\begin{tabular}{|c|c|c|c|c|c|c|c|c|}
\hline & \multirow[t]{2}{*}{ N } & \multirow[t]{2}{*}{ Mean } & \multirow{2}{*}{$\begin{array}{l}\text { Std. } \\
\text { Deviation }\end{array}$} & \multirow{2}{*}{$\begin{array}{l}\text { Std. } \\
\text { Error }\end{array}$} & \multicolumn{2}{|c|}{ 95\% Confidence Interval for Mean } & \multirow[t]{2}{*}{ Minimum } & \multirow[t]{2}{*}{ Maximum } \\
\hline & & & & & Lower Bound & Upper Bound & & \\
\hline IB Group & 18 & 16.6221 & 1.25506 & .29582 & 15.9870 & 17.2352 & 15.00 & 19.00 \\
\hline OB Group & 18 & 16.7500 & 1.48769 & .35065 & 16.0102 & 17.4898 & 14.50 & 19.00 \\
\hline Control Group & 18 & 9.3611 & 1.65214 & .38941 & 8.5395 & 10.1827 & 6.50 & 12.00 \\
\hline Total & 54 & 14.2407 & 3.77147 & .51323 & 13.2113 & 15.2702 & 6.50 & 19.00 \\
\hline
\end{tabular}


Table 5 One-way ANOVA (post-test)

\begin{tabular}{llllll}
\hline & Sum of Squares & df & Mean Square & $F$ & Sig. \\
\hline Between Groups & 643.065 & 2 & 321.532 & 147.990 & .000 \\
Within Groups & 110.806 & 51 & 2.173 & & \\
Total & 753.870 & 53 & & & \\
\hline
\end{tabular}

As depicted in Table 6, on the post-test, both input-based and output-based groups scored significantly higher than the control group $(p=.000)$. However, there was no significant difference between input-based and output-based groups $(p=.961)$.

\section{Results of three groups' delayed post-test}

Table 7 shows that the mean in the control group differs significantly from two other groups. The mean for input-based, output-based, and control groups are 16.6389, 16.6111, and 9.6111 respectively. To describe the statistical significance of the three groups' mean in delayed test, One- way ANOVA was applied, and the results of the test were interpreted from two points: Level of significance and F-ratio. The results of the statistical operations are analyzed in Table 8.

Based on Table 8, a significant main effect of group was found in the delayed post-test $(\mathrm{F} 2,51=251.070, p=.000)$. To clarify which group outperformed other groups in the delayed post-test, the Post-hoc Scheffe test was conducted to compare the specific mean effectiveness among the three groups. Data are illustrated in Table 9.

Scheffe post hoc analyses revealed that on the delayed post-test, both input and output groups scored significantly higher than the control group $(p=.000)$. There was, however, no significant difference between input and output groups $(p=.997)$. Therefore, it can be concluded that the instruction was effective and time interval did not have any effect on the performance of groups in delayed test.

Figure 1 shows the mean changes of scores on the productive vocabulary pre-test, post-test, and delayed post-test across all groups. As displayed in Fig. 1, the input-based and output-based groups had the highest mean score in post-test and delayed post-test, whereas the control group had the lowest mean score in both post-test and delayed post-test. In pre-test, however, the mean scores were very close to each other.

Table 6 Post-hoc Test, Multiple Comparisons (Post-tests

\begin{tabular}{|c|c|c|c|c|c|c|}
\hline \multicolumn{7}{|c|}{ Dependent Variable: Post-test } \\
\hline \multicolumn{7}{|l|}{ Scheffe } \\
\hline \multirow[t]{2}{*}{ (I) Groups } & \multirow[t]{2}{*}{ (J) Groups } & \multirow[t]{2}{*}{ Mean Difference $(\mid-J)$} & \multirow[t]{2}{*}{ Std. Error } & \multirow[t]{2}{*}{ Sig. } & \multicolumn{2}{|c|}{ 95\% Confidence Interval } \\
\hline & & & & & Lower Bound & Upper Bound \\
\hline \multirow[t]{2}{*}{ IB Group } & OB Group & -.13889 & .49133 & .961 & -1.3777 & 1.1000 \\
\hline & Control Group & $7.25000^{*}$ & .49133 & .000 & 6.0111 & 8.4889 \\
\hline \multirow[t]{2}{*}{ OB Group } & IB Group & .13889 & .49133 & .961 & -1.1000 & 1.3777 \\
\hline & Control Group & $7.38889^{*}$ & .49133 & .000 & 6.1500 & 8.6277 \\
\hline \multirow[t]{2}{*}{ Control Group } & IB Group & $-7.25000^{*}$ & .49133 & .000 & -8.4889 & -6.0111 \\
\hline & OB Group & $-7.38889^{*}$ & .49133 & .000 & -8.6277 & -6.1500 \\
\hline
\end{tabular}

* The mean difference is significant at the 0.05 level 
Table 7 Descriptive Statistics (delayed tests)

\begin{tabular}{|c|c|c|c|c|c|c|c|c|}
\hline \multicolumn{9}{|l|}{ Delayed post } \\
\hline & \multirow[t]{2}{*}{$\mathrm{N}$} & \multirow[t]{2}{*}{ Mean } & \multirow{2}{*}{$\begin{array}{l}\text { Std. } \\
\text { Deviation }\end{array}$} & \multirow{2}{*}{$\begin{array}{l}\text { Std. } \\
\text { Error }\end{array}$} & \multicolumn{2}{|c|}{ 95\% Confidence Interval for Mean } & \multirow[t]{2}{*}{ Minimum } & \multirow[t]{2}{*}{ Maximum } \\
\hline & & & & & Lower Bound & Upper Bound & & \\
\hline IB Group & 18 & 16.6389 & .72367 & .17057 & 16.2790 & 16.9988 & 15.50 & 18.50 \\
\hline OB Group & 18 & 16.6111 & 1.00814 & .23762 & 16.1098 & 17.1124 & 14.50 & 19.00 \\
\hline Control Group & 18 & 9.6111 & 1.40958 & .33224 & 8.9101 & 10.3121 & 7.00 & 11.00 \\
\hline Total & 54 & 14.2870 & 3.50283 & .47667 & 13.3309 & 15.2431 & 7.00 & 19.00 \\
\hline
\end{tabular}

\section{Discussion and conclusion}

This study investigated the effects of input-based and output-based activities on productive knowledge of vocabulary. The first and second research questions asked were: Do input-based activities and output-based activities have any significant effect on Iranian pre-intermediate EFL learners' productive knowledge of vocabulary? The results indicated that learners who received input-based activities along with those who received output-based activities significantly outperformed the control group in the post-test and delayed post-test. Thus, the answer to the first and second research questions is affirmative. The results presented in the previous section confirm that both IB and OB groups improved significantly from the pre-tests to post-tests, and there was no significant difference between the post-tests and the delayed post-tests. Overall, despite both group's equal performance from post-tests to delayed tests, both IB and OB groups evidenced significant gains from pre-tests to delayed post-tests, and, therefore, both instructional conditions led to improved performance.

The third research question was: Which instructional approach (input-based activities vs. output-based activities) is more effective in productive knowledge of vocabulary? The results of post-hoc multiple comparisons test performed on post-test and delayed post-test (Tables 6 and 9) showed that both of the IB and the OB groups significantly outperformed the control group, but there was no significant difference between the two experimental groups. Therefore, the overall achievement of the two experimental groups was very similar; no significant difference emerged between the IB and the OB groups on post-test and delayed post-test. In other words, input-based activities and output-based activities had similar effects on participants' performance in the productive knowledge of vocabulary.

The results of this study are in line with Shintani (2011) who investigated the comparative effects of two types of treatment - one of which emphasized input and the other output - on the vocabulary acquisition of young EFL learners. Shintani found out that both input-based and production-based instruction lead to both receptive and productive vocabulary knowledge. In general, the results of Shintani's study show similar levels of effects for input-based and production-based instruction on vocabulary acquisition. The results further confirm the findings of Gholami and Farvardin (2017) who

Table 8 One-way ANOVA (delayed post-tests)

\begin{tabular}{llllll}
\hline & Sum of Squares & df & Mean Square & F & Sig. \\
\hline Between Groups & 590.343 & 2 & 295.171 & 251.070 & .000 \\
Within Groups & 59.958 & 51 & 1.176 & & \\
Total & 650.301 & 53 & & & \\
\hline
\end{tabular}


Table 9 Post-hoc Test, Multiple Comparisons (Delayed Post-tests)

\begin{tabular}{|c|c|c|c|c|c|c|}
\hline \multicolumn{7}{|c|}{ Dependent Variable: Delayedpost } \\
\hline \multicolumn{7}{|l|}{ Scheffe } \\
\hline \multirow[t]{2}{*}{ (I) Groups } & \multirow[t]{2}{*}{ (J) Groups } & \multirow[t]{2}{*}{ Mean Difference (I-J) } & \multirow[t]{2}{*}{ Std. Error } & \multirow[t]{2}{*}{ Sig. } & \multicolumn{2}{|c|}{ 95\% Confidence Interval } \\
\hline & & & & & Lower Bound & Upper Bound \\
\hline \multirow[t]{2}{*}{ IB Group } & OB Group & .02778 & .36143 & .997 & -.8835 & .9391 \\
\hline & Control Group & $7.02778^{*}$ & .36143 & .000 & 6.1165 & 7.9391 \\
\hline \multirow[t]{2}{*}{ OB Group } & IB Group & -.02778 & .36143 & .997 & -.9391 & .8835 \\
\hline & Control Group & $7.00000^{*}$ & .36143 & .000 & 6.0887 & 7.9113 \\
\hline \multirow[t]{2}{*}{ Control Group } & IB Group & $-7.02778^{*}$ & .36143 & .000 & -7.9391 & -6.1165 \\
\hline & OB Group & $-7.00000^{*}$ & .36143 & .000 & -7.9113 & -6.0887 \\
\hline
\end{tabular}

*. The mean difference is significant at the 0.05 level

examined the impacts of input-based and output-based instructions on collocational knowledge of EFL learners. They concluded that both input and output groups outperformed the control group on the immediate and delayed post-tests. However, in their study, there were no significant differences between the input and output groups on the post-tests. The findings are also in line with the notion that using the increased tokens of input (i.e., input flood) can absorb learners' attention to the target forms (Reinders \& Ellis, 2009). Attention is "the vita and adequate condition for the conversion of input into intake" (Schmidt, 2001, p. 209). In this study, the input-based group outperformed the control group in both post-test and delayed post-tests.

However, the results of this study are in contrast with Asaei and Rezvani (2015) who found that there is a significant difference between the input-based and output-based instructions in productive collocational knowledge of Iranian EFL learners $(p=.000<.05)$. The findings of the study are also in contrast with the Ellis' (2003) claim that output-based instruction could better improve the productive collocational knowledge of

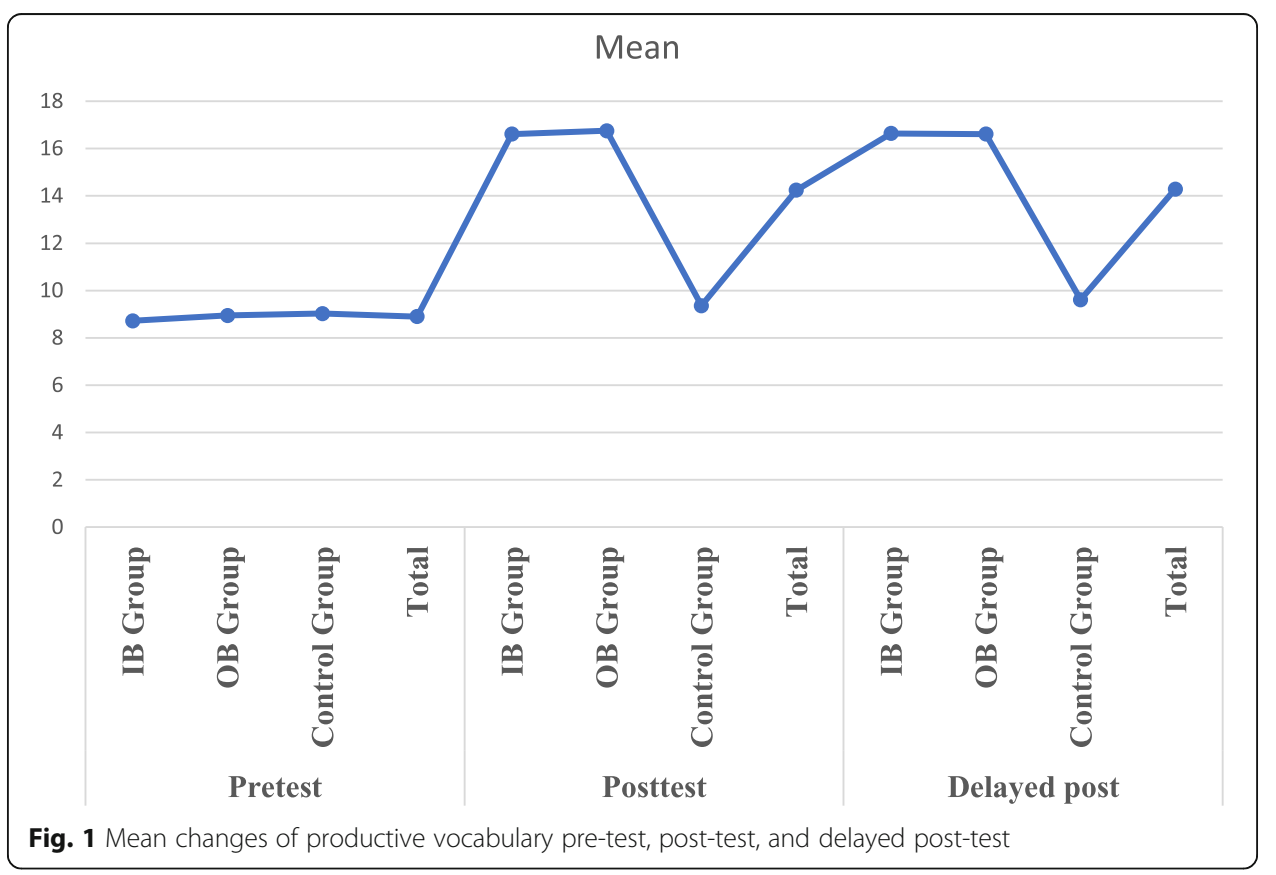


L2 learners in the long-term compared with input-based instruction. Although, in this study, there was a slight difference between the output and input groups, no significant difference was found in the long-term retention of the L2 vocabulary.

This study tried to investigate the effect of input-based and output-based activities on L2 productive knowledge of vocabulary. The results also divulged the significant impacts of input-based and output-based activities on boosting L2 vocabulary recall and retention. The findings of this study are mainly auspicious to EFL learners who particularly aimed to promote their vocabulary knowledge. The results of the study may have some pedagogical implications for ESL/EFL instructors as well. Input-based and output-based activities can help teachers implement efficacious techniques to increase the L2 learners' awareness and consciousness. Moreover, EFL/ESL teachers can make the teaching vocabulary more beneficial by utilizing IB or OB activities.

Moreover, the present study helps our understanding of the relative influence of input-based and output-based activities on vocabulary acquisition for young EFL learners. As for the pedagogical implications, this study provides evidence that input-based tasks can be successfully implemented in EFL classrooms for students and are at least as effective as output-based activities where vocabulary learning is concerned.

Abbreviations

EFL: English as a Second Language; ESL: English as a Foreign Language; IB: Input Based; OB: Output Based;

OQPT: Oxford Quick Placement Test; SPSS: Statistical Package for the Social Sciences

Acknowledgements

Not applicable.

Funding

The study did not receive any funding.

Availability of data and materials

Please contact corresponding author for data requests.

Authors' contributions

All authors of the research had more or less equal contributions in the process of conception and design, acquisition of data, and analysis and interpretation of data. They have all been involved in revising the manuscript critically to the same extent. All take public responsibility for the whole content. All are equally accountable for all aspects of the work. All authors read and approved the final manuscript.

Competing interests

The authors declare that he has no competing interests.

\section{Publisher's Note}

Springer Nature remains neutral with regard to jurisdictional claims in published maps and institutional affiliations.

Author details

'Department of English, Faculty of Humanities, Shahrekord Branch, Islamic Azad University, Shahrekord, Iran.

${ }^{2}$ Department of English, Faculty of Humanities, Najafabad Branch, Islamic Azad University, Najafabad, Iran.

Received: 21 October 2018 Accepted: 15 January 2019

Published online: 21 January 2019

References

Allen, L. (2000). Form-meaning connections and the French causative: An experiment in input processing. Studies in Second Language Acquisition, 22(1), 69-84.

Anderson, J. R. (1993). Rules of the mind. Hillsdale: Lawrence Erlbaum.

Asaei, R., \& Rezvani, E. (2015). The effect of explicit vs. implicit instruction on Iranian EFL learners' use of collocations in L2 writing. Journal of Applied Linguistics and Language Research, 2(3), 1-22.

Benati, A. (2005). The effects of PI, TI, and MOI in the acquisition of English simple past tense. Language Teaching Research, $9(1), 67-113$. 
DeKeyser, R. M., \& Sokalski, K. J. (2001). The differential role of comprehension and production practice. Language Learning, $51(1), 81-112$.

Ellis, N. (1994). Vocabulary acquisition: The implicit ins and outs of explicit cognitive mediation. In N. Ellis (Ed.), Implicit and explicit learning of language (pp. 213-282). London: Academic Press.

Ellis, N., \& Beaton, A. (1993). Factors affecting the learning of foreign language vocabulary: Imagery keyword mediators and phonological short-term memory. The Quarterly Journal of Experimental Psychology Section, 46(3), 533-558.

Ellis, R. (2003). Task-based language learning and teaching. Oxford: Oxford University Press.

Ellis, R. (2012). Language teaching research and pedagogy. West Sussex: Wiley Blackwell.

Erlam, R., Loewen, S., \& Philp, R. (2009). Implicit and explicit corrective feedback and the acquisition of L2 grammar. In R. Ellis, S. Loewen, C. Elder, R. Erlam, J. Philp, \& H. Reinders (Eds.), Implicit and explicit knowledge in second language learning, testing and teaching (pp. 303-332). Bristol, Buffalo, Toronto: Multilingual matters.

Farley, A. (2001a). Authentic processing instruction and the Spanish subjunctive. Hispania, 85(2), 289-299.

Farley, A. (2001b). Processing instruction and meaning-based output instruction: A comparative study. Spanish Applied Linguistics, 5(2), 57-93.

Gholami, N., \& Farvardin, M. T. (2017). Effects of input - based and output - based instructions on Iranian EFL learners' productive knowledge of collocations. International Journal of Applied Linguistics and English Literature, 6(3), 123-130.

Hills., L. A. (1980). Anecdotes in American English. Oxford: Oxford University Press.

Izumi, S. (2002). Output, input enhancement, and the noticing hypothesis. Studies in Second Language Acquisition, 24(4), 541-577.

Krashen, S. (1982). Principles and practice in second language acquisition. Oxford: Pergamon Press.

Krashen, S. (1985). The input hypothesis: Issues and implications. London/New York: Longman.

Krashen, S. (1998). Comprehensible output? System, 26(2), 175-182.

Laufer, B., \& Nation, P. (1999). A vocabulary-size test of controlled productive ability. Language Testing, 16(1), 33-51.

Lee, J. F., \& Benati, A. G. (2009). Research and perspectives on processing instruction. Berlin: Walter de Gruyter

Lee, J. F., \& VanPatten, B. (2003). Making communicative language teaching happen. New York: McGraw-Hill.

Long, M. (1991). Focus on form: A design feature in language teaching methodology. In K. de Bot, R. Ginsberg, \& C. Kramsch (Eds.), Foreign language research in cross-cultural perspective (pp. 39-52). Amsterdam: Benjamins.

Malekshahi, N., \& Amini Harsini, M. (2017). The effect of input-based and output-based tasks on the intermediate Iranian EFL learners' writing achievement in terms of coherent writing. International Journal of Applied Linquistics \& English Literature, 7(1), 184-192.

Morgan-Short, K., \& Bowden, H. W. (2006). Processing instruction and meaningful output-based instruction. Studies in Second Language Acquisition, 28(1), 31-65.

Rassaei, E. (2012). The effects of input -based and output -based instruction on L2 development. The Electronic Journal for English as a Second Language, 16(3), 1-25.

Redman, S. (1997). English vocabulary in use pre-intermediate and intermediate. Cambridge: Cambridge University Press.

Reinders, H., \& Ellis, R. (2009). The effects of two types of input on intake and the acquisition of implicit and explicit knowledge. In R. Ellis et al. (Eds.), Implicit and explicit knowledge in second language learning testing and teaching (pp. 282-302). Bristol: Multilingual Matters.

Salimi, A., \& Shams, K. (2016). The effect of input - base and output - based instruction on EFL learners' autonomy in writing. Theory and Practice in Language Studies, 6(3), 525-533.

Schmidt, R. (2001). Attention. In P. Robinson (Ed.), Cognition and second language instruction (pp. 3-32). Cambridge: Cambridge University Press.

Shintani, N. (2011). A comparative study of the effects of input-based and production-based instruction on vocabulary acquisition by young EFL learners. Language Teaching Research, 15(2), 137-158.

Swain, M. (1985). Communicative competence: Some roles of comprehensible input and comprehensible output in its development. In S. Gass \& C. Madden (Eds.), Input in second language acquisition. Cambridge, MA: Newbury House.

Swain, M. (1995). Three functions of output in second language learning. In G. Cook \& B. Seidlhofer (Eds.), Principle and practice in applied linguistics: Studies in honor of H. G. Widdowson (pp. 125-144). Oxford: Oxford University Press.

Swain, M. (2000). The output hypothesis and beyond: Mediating acquisition through collaborative dialogue. In J. Lantolf (Ed.), Sociocultural theory and second language learning (pp. 97-114). Oxford: Oxford University Press.

Swain, M. (2005). The output hypothesis: Theory and research. In E. Hinkel (Ed.), Handbook on research in second language teaching and learning (pp. 471-483). Mahwah, NJ: Lawrence Erlbaum Associates.

Swain, M., \& Lapkin, S. (1995). Problems in output and the cognitive processes they generate: A step towards second language learning. Applied Linguistics, 16(3), 371-391.

Toth, B. (2006). Processing instruction and a role for output in second language acquisition. Language Learning, 56(2), 319-385.

VanPatten, B. (1993). Grammar teaching for the acquisition-rich classroom. Foreign Lanquage Annals, 26(4), 435-450.

VanPatten, B. (1996). Input processing and grammar instruction in second language acquisition: Theory and research. Norwood: Ablex.

VanPatten, B. (2002). Processing instruction: An update. Language Learning, 52(1-2), 755-803.

VanPatten, B. (2004). Input processing in second language acquisition. In B. VanPatten (Ed.), Processing instruction: Theory, research, and commentary (pp. 5-32). Mahwah: Lawrence Erlbaum.

VanPatten, B., \& Cadierno, T. (1993). Explicit instruction and input processing. Studies in Second Language Acquisition, 15(2), 225-244.

VanPatten, B., \& Wong, W. (2004). Processing instruction and the French causative: Another replication. In B. VanPatten (Ed.), Processing instruction: Theory, research, and commentary (pp. 97-118). Mahwah, NJ: Lawrence Erlbaum.

Wong, W. (2004a). The nature of processing instruction. In B. VanPatten (Ed.), Processing instruction: Theory, research, and commentary (pp. 33-63). Mahwah: Lawrence Erlbaum.

Wong, W. (2004b). Processing instruction in French: The roles of explicit information and structured input. In B. VanPatten (Ed.), Processing instruction: Theory, research, and commentary (pp. 187-205). Mahwah: Lawrence Erlbaum. 